\title{
Low-Income Families in New Hampshire
}

\author{
B Y A L LISON CHURILLA
}

C ompared to the nation, New Hampshire has the lowest percentage of people living in poverty and one of the lowest child poverty rates in the nation. ${ }^{1,2}$ On a variety of other measures of quality of life, New Hampshire has maintained similarly strong national rankings. Personal, family, and household incomes are higher than national averages, adults in New Hampshire tend to be well educated, and employment remains strong. ${ }^{3,4}$

Despite this overall well-being, one in seven families in New Hampshire was low-income in 2004, including 83,000 adults and 62,000 children in approximately 48,000 families. ${ }^{5}$

Families' economic stability is often understood in terms of poverty status, but poverty status is a poor indicator of families' ability to meet their basic needs. Families must be able to accumulate the necessary resources to finance their housing, food, transportation, child care, healthcare and other necessities. This typically requires earnings that are two to three times the federal poverty level. Estimating a basic needs budget for families in the state, a recent report estimates that a family of four in New Hampshire needs an annual family income between $\$ 37,000$ and $\$ 49,000 .{ }^{6}$ For perspective, a family of four was low-income in 2004 if their family income was below $\$ 37,700$, an amount that just skims the bottom of this range.

TABle 1. Composition of Low-Income Families, New HAMPSHire (2004)

\begin{tabular}{lccc}
\hline & $\begin{array}{c}\text { Low-Income } \\
\text { Families }\end{array}$ & $\begin{array}{c}\text { All } \\
\text { Families }\end{array}$ & $\begin{array}{c}\text { Percent } \\
\text { Low-Income }\end{array}$ \\
\hline Total Adults & 83,000 & 713,000 & $12 \%$ \\
Total Children & 62,000 & 298,000 & $21 \%$ \\
Total Families & 48,000 & 338,000 & $14 \%$ \\
$\quad$ Married Couple Family & 24,000 & 272,000 & $9 \%$ \\
$\quad$ Male-Headed Family & 3,000 & 18,000 & $18 \%$ \\
Female-Headed Family & 21,000 & 47,000 & $44 \%$ \\
\hline
\end{tabular}

Source: 2005 ACS
And while the state has seen progress in its national rankings over the last five years, many low-income families in New Hampshire have experienced declines in their economic well-being. Recent trends in employment and housing have contributed to this decline. The struggles of low-income families are especially troubling since we have seen strong economic growth in recent years.

To inform policy discussion on the challenges facing lowincome families in New Hampshire, we identify individual and structural characteristics that heighten families' risk of low income. This brief profiles low-income families in New Hampshire, documents recent trends in the economic status of low-income families in the state, and identifies characteristics of families that experience particular obstacles to economic stability. The report concludes with a discussion of policies that impact these families.

\section{Marital Status and Employment Influence Low-Income Status}

It is useful to start by identifying broad characteristics of low-income families in the state. This section provides a brief background on the demographic characteristics of low-income family heads, ${ }^{7}$ followed by a discussion of how marital and employment status are related to being a low-income family in New Hampshire.

Families headed by middle-aged adults experience the lowest risk of low income. Less than one in ten family heads in their forties or fifties headed a low-income family in 2004, compared to almost one in three family heads under thirty years of age. Risk of low income again rises for older family heads, likely related to retirement from the labor force, reliance on a fixed income, and medical expenses.

Adults that head New Hampshire's low-income families tend to have lower levels of education. One in five lowincome family heads did not have a high school degree in 2004, compared to one in twelve family heads overall. Figures in Table 2 indicate that families' risk of low income tends to drop as family heads' education increases. 
Table 2. Characteristics of Low-Income Family Heads, New Hampshire (2004)

\begin{tabular}{lccc}
\hline & $\begin{array}{c}\text { Low-Income } \\
\text { Families }\end{array}$ & $\begin{array}{c}\text { All } \\
\text { Families }\end{array}$ & $\begin{array}{c}\text { Percent } \\
\text { Low-Income }\end{array}$ \\
\hline Total Family Heads & 72,000 & 610,000 & $12 \%$ \\
Age & & & \\
Under 30 Years & 13,000 & 47,000 & $28 \%$ \\
30-39 Years & 15,000 & 124,000 & $12 \%$ \\
40-49 Years & 15,000 & 173,000 & $9 \%$ \\
50-59 Years & 9,000 & 129,000 & $7 \%$ \\
60-69 Years & 8,000 & 77,000 & $11 \%$ \\
70 Years and Older & 12,000 & 0,000 & $20 \%$ \\
Race/Ethnicity & & & \\
White (non-Hispanic or Latino) & 65,000 & 579,000 & $11 \%$ \\
Black (non-Hispanic or Latino) & 1,000 & 4,000 & $31 \%$ \\
Hispanic or Latino(a) & 2,000 & 7,000 & $34 \%$ \\
Other & 4,000 & 20,000 & $18 \%$ \\
Education & & & \\
Less than High School Degree & 14,000 & 54,000 & $27 \%$ \\
High School Degree & 44,000 & 300,000 & $15 \%$ \\
Associate Degree & 4,000 & 56,000 & $8 \%$ \\
Bachelor's Degree or Higher & 10,000 & 201,000 & $5 \%$ \\
\hline Source 2005 ACS & &
\end{tabular}

Source: 2005 ACS

Low income is also linked to whether New Hampshire's family heads are immigrants or are disabled. Immigrant family heads are over-represented among low-income family heads. In 2004, 21 percent of immigrant family heads were concentrated in low-income families. Employment disability is another risk factor. In 2004, 18 percent of low-income family heads had an employment disability, compared to 6 percent of family heads overall. ${ }^{8}$

Perhaps two of the most striking characteristics related to low-income in New Hampshire are marital status and employment. Marriage tends to increase many families' economic stability. Figures in Table 1 show that risk of low-income is lowest for families headed by a married couple and highest for female-headed families. Divorce tends to be the most common reason that families are headed by one adult. Male heads at all family income levels were most likely to be divorced, as were female heads of middle- and high-income families. ${ }^{9}$ In contrast, female heads of low-income families were most likely to have never been married.

These links between marital status and low income suggest that, for many families in New Hampshire, maintaining middle-class status depends on their potential to draw income from two earners. This is confirmed by family employment figures, which show that only 5 percent of families with two earners were low-income in 2004. Conversely, 24 percent of families with one earner were low-income.

\section{Modest Gains for Low-Income Families Counteracted by Rising Housing Costs and Lower Labor Force Participation}

Low-income families have experienced some modest gains in recent years. Between 1999 and 2004, the number of lowincome families grew at a slower pace than the total number of families in New Hampshire. There was 1 percent growth in the number of low-income families in New Hampshire over these years, compared to 4 percent growth in the total number of families in the state. The number of low-income families with children grew by 3 percent between 1999 and 2004 , but it is encouraging that the actual number of children living in low-income families declined 7 percent over those five years.

These modest gains have been offset by indicators suggesting that New Hampshire's low-income families have lost important ground in the last five years. Economically, lowincome families are faring worse than they were before the turn of the century. Low-income families' median income went down by 9 percent between 1999 and 2004 from about $\$ 7,300$ per family member to $\$ 6,700 .{ }^{10}$ Labor force participation among adults in these families also declined. Seventytwo percent of low-income families had a working adult in 1999, compared to 67 percent in 2004. As a result of these and other factors, there was a marked increase in the share of low-income families who experienced poverty or severe poverty over these five years. ${ }^{11}$ The share of low-income families living in poverty increased from 29 to 38 percent between 1999 and 2004 (a 30 percent increase) and the share living in severe poverty increase from 11 to 15 percent (a 40 percent increase).

Investment in a home can be one of the first ways that low-income families strengthen their economic security. Housing quality and affordability can also facilitate adults' ability to maintain steady employment, and has been linked to positive educational and behavioral outcomes in children. ${ }^{12}$ Home ownership is one opportunity for low-income families to invest and build family assets, but many lowincome families rent their
The share of low-income families living in poverty increased 30 percent between 1999 and 2004, and the share living in severe poverty increased 40 percent. 
Figure 1. HoMe OWNership by InCOME LeVel, NeW HAMPSHIRE (2004)

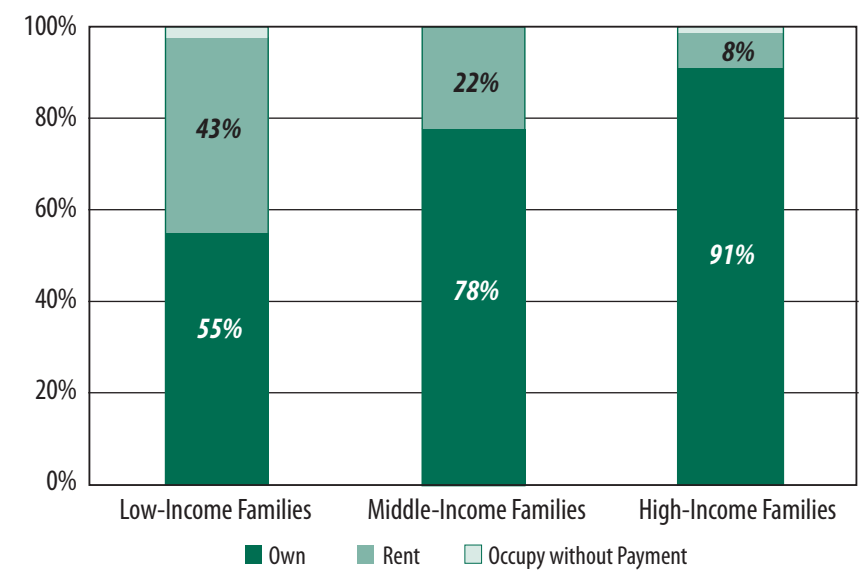

Source: 2005 ACS

home. In 2004, 43 percent of low-income families rented their housing, while 55 percent were homeowners. Compared to low-income families, much larger shares of middleand high-income families owned their home in 2004.

Economic strain has been compounded by rising housing costs. In 1999, one in three low-income families that rented or owned their residence faced a "critical housing need," spending more than half of their family income on rent or mortgage alone. In 2004, this figure rose to 52 percent of the state's low-income families. In other words, the number of low-income families facing a critical housing need in the state increased 55 percent between 1999 and 2004.

For low-income homeowners, median property value was in the range of $\$ 175,000$ to $\$ 199,999$ in 2004 . Since 1999, low-income home owners saw a 13 percent increase in monthly mortgage payments. Low-income families who rented their home experienced a 25 percent increase in median rental costs over the same time period. These trends especially impact low-income families. Because a larger share of low-income families rent their residences and rental costs are variable, low-income families tend to be more vulnerable to rising housing costs. Families at other income levels that rented their residences did not see as steep a climb in their rental costs.

In 2004, almost one in three low-income families in New Hampshire experienced crowding in their residence..$^{13}$ These families also tend to have lived in their residence for shorter periods of time. Half of low-income families had been in their residence for less than five years in 2004, compared to one-third of families at other income levels.

Work does not necessarily lift families out of the low-income group, but full-time employment and adequate wages are important for families' economic stability. In 2004, at least one adult was employed in two-thirds of the state's low-income families. This represents a 7 percent drop from 1999. Only 30 percent of low-income families had a full-time worker in their household in 2004.

Many full-time workers from low-income families were employed in personal care and service occupations like retail sales ( 8 percent) and child care (4 percent). The median hourly wages for these two occupations were $\$ 8.98$ and $\$ 8.06$ in 2004, respectively. ${ }^{14}$ Of the 15,000 full-time workers in low-income families, 28 percent earned an annual income that averaged less than or equal to the federal minimum wage. ${ }^{15}$

\section{Families Headed by Young Adults, Usually with Young Children, are Disproportionately Low-Income}

A substantial portion of low-income families in the state are headed by young adults in their twenties and thirties (43 percent). These are the years when young adults are starting new careers, establishing their own families, and moving into their first homes. Because of these transitions, it seems logical that their families are less economically stable than families headed by middle aged or older adults.

But economic instability faced by young adults has a direct impact on young children living in these families. Young children are most likely to live in homes headed by young adults. ${ }^{16}$ In 2004, 76 percent of all families with young children were headed by adults in their twenties and thirties. Young adults' instability therefore puts young children at a heightened risk of low income. Whereas 14 percent of the state's families were low-income in 2004, 23 percent of families with young children were low-income.

Families with children of all ages are at considerably greater risk of low income than families without children. In New Hampshire, 20 percent of families with children were low income in 2004, compared to 9 percent of families without children.

As indicated above, there has been some improvement in children's well-being in recent years. Between 1999 and 2004, there was a 7 percent reduction in the number of children living in low-income families. But children living in single mother families have not seen parallel improvements in their well-being. Over the same five years that there was a decline in the number of children living in low-income families, 
the number of children living in low-income, single mother families increased 14 percent. Single mother families with young children have an even greater risk of low income: 71 percent were low-income in 2004.

\section{Single Mother Families Face Even Greater Risk of Low Income}

Single mother families are especially vulnerable to lowincome status. Fifty-eight percent of single mother families-or an estimated 19,000 families in New Hampshire-were low-income in 2004. Of the 62,000 children living in low-income families in the state in 2004, over half lived in a single mother family.

Recent trends in the well-being of single mother families are not encouraging because their risk of low income has escalated. There was a disproportionately high increase in the number of low-income, single mother families in New Hampshire between 1999 and 2004. The total number of single mother families in the state grew by 10 percent over the same time period and the total number of families overall grew by only 4 percent.

Single mothers are, by definition, unmarried, but this does not necessarily mean that they live and meet household expenses on their own. One in four low-income, single mothers lived with an unmarried partner in 2004, the majority of which were opposite-sex partnerships (94 percent).${ }^{17}$ It is likely that unmarried partners contribute to household expenses and maintenance, but this income is often not enough to raise families above low-income status. In 2004, 50 percent of single mother families (compared to 58 percent) would have met low-income criteria even after including partners' income.

There was a noticeable decline in low-income single

Figure 2. Low-Income, Single Mothers' Labor ForCe Participation, New Hampshire (1999 \& 2004)

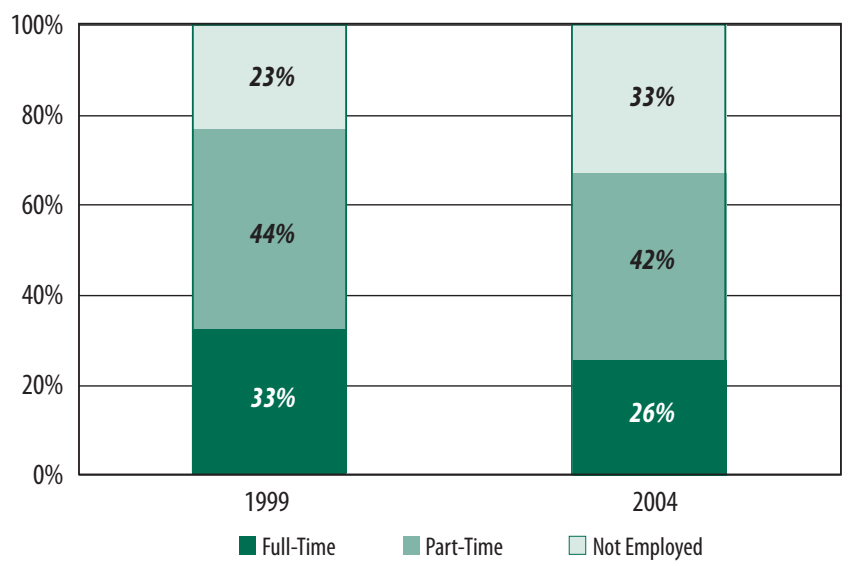

Source: 2000 PUMS and 2005 ACS
Table 3. Low-Income, Single Mothers'

Participation in Government Assistance

Programs, New Hampshire (2004)

$\begin{array}{lc}\text { Percent of } & \text { Median Annual } \\ \text { Low-Income, } & \text { Benefit } \\ \text { Single Mother } & \\ \text { Families } & \end{array}$

Type of Assistance Program

$\begin{array}{lll}\text { Food Stamps } & 36 \% & \$ 1,560 \\ \text { Cash Public Assistance or TANF } & 14 \% & \$ 1,100 \\ \text { Supplemental Security } & 13 \% & \$ 6,800 \\ \text { Social Security } & 10 \% & \$ 7,100\end{array}$

Number of Programs in which Family Participates

\begin{tabular}{lll}
0 programs & $56 \%$ & NA \\
1 program & $23 \%$ & NA \\
2 or more programs & $21 \%$ & NA \\
\hline
\end{tabular}

Source: 2005 ACS

mothers' participation in the paid labor force between 1999 and 2004. Sixty-seven percent of these women were employed as full- or part-time workers in 2004, whereas the figure stood at 77 percent in 1999. The bulk of the decline was in full-time employment.

The majority of working, low-income, single mothers were employed part-time, but slightly over one-third were employed full-time in the labor force. All were concentrated primarily in low-skill service occupations, but mothers who worked full-time tended to take on jobs with greater sensitivity to their family schedules and responsibilities. The most widely held full-time jobs were as child care workers (13 percent), bus drivers (7 percent), and janitors and building cleaners (6 percent).

As a result of these families' low earning power, government assistance is a necessary resource for many single mother families as they try to provide for their families. Forty-four percent of low-income, single mother families participated in at least one government assistance program in 2004. The Food Stamp Program was the most widely used, with one-third of low-income, single mother families making use of this resource. Other public programs low-income mothers used included cash public assistance, Social Security, and the Supplemental Security Program..$^{18}$ One in five families participated in two or more assistance programs.

Over the same five years
that there was a decline
in the number of children
living in low-income
families, the number of
children living in low-
income, single mother
families increased 14
percent.


Most low-income, single mother families rented their home in 2004 (64 percent), which constrains families' assetbuilding opportunities. The strain imposed by housing costs are severe for many families in the state, but housing costs are even more severe for single mother families that are lowincome. Low-income mothers who rented their home paid, on average, 64 percent of their family income to monthly rent payments. ${ }^{19}$ For low-income mothers that owned their home, an average of 45 percent of their family income went toward mortgage payments. It follows that 63 percent of low-income, single mother families with a monthly housing payment faced a critical housing need in 2004.

Between 1999 and 2004, growth in the number of lowincome, single mother families facing a critical housing need surpassed growth for low-income families in general (up 78 percent). This is because the cost of housing in New Hampshire rose dramatically over those five years. Low-income mothers saw a 28 percent increase in their monthly rent over that time or, if they owned their home, a 5 percent increase in their monthly mortgage payments.

Low-income single mother families' housing is also often characterized by greater instability. Over one-third of these families lived in homes where crowding posed an issue. ${ }^{20}$ Two-thirds had lived in their residence for less than five years. Instability in housing may lead to instability in children's schooling, families' social networks, and mothers' employment.

\section{Policy Considerations}

Low family income means that families are likely to struggle to meet their basic needs. ${ }^{21}$ Economic stability depends on whether these families can secure sufficient earnings, government assistance, and social support to sustain a basic family budget. The following policy considerations focus on two broad areas: adults' workforce preparation and attachment and family income support.

\section{Adults' Workforce Preparation and Attachment}

Workforce preparation policies can facilitate placement and promotion for workers that may otherwise move laterally among low-skill, low-paying jobs. Analyses in this report show that, when adults in low-income families are employed in the labor force, they work at jobs that are typically lowskill and require little advanced education. Family income tends to increase as adults obtain higher levels of education. But higher education is less accessible in New Hampshire than in other states because of its high price tag. ${ }^{22}$ Greater accessibility to attaining higher education depends on reducing costs associated with school enrollment and extending financial support to families in need.
Low-income, working adults need to obtain marketable skills. These skills can translate into jobs that offer higher pay, access to health benefits and paid leave, and schedules that are flexible for working parents. In New Hampshire, up to 30 percent of the state's participants in the Tempo-
Family income tends to increase as adults obtain higher levels of education. But higher education is less accessible in New Hampshire than in other states because of its high price tag.

Families (TANF) program are permitted to enroll in vocational educational training for a maximum of 12 months. ${ }^{23}$ After that period, participants are required to secure paid or unpaid employment for at least twenty hours per week. Some suggest extending the period for which training fulfills the work requirement (i.e., longer than 12 months), providing training support to families whose income sets them just above TANF eligibility requirements, and extending TANF five-year eligibility time limits for families headed by a parent working full-time.

Workforce attachment policies are sensitive to conditions outside of the workplace that may influence workers' job attachment, such as child care, health care, and housing stability. For example, parents' attachment to the full-time workforce depends on the availability and accessibility of quality child care. This is particularly important for single parents, whose ability to stay in the workforce is contingent on reliable child care. Child care subsidies are available to families in the state that meet income eligibility requirements, but only 4,500 families made use of the subsidies in $2004 .{ }^{24}$ Indeed, only 9 percent of New Hampshire's lowincome families accessed this resource, signaling a need to promote the program and make it more accessible for families with children.

Also related to workforce attachment, figures in this brief showed a dramatic rise in the number of low-income families experiencing a critical housing need since 1999. Housing affordability is particularly relevant in New Hampshire, where housing costs are comparatively higher than in other areas of the United States. ${ }^{25}$ Other states have found that rental assistance and down payment assistance can help alleviate housing instability for low-income families. In states that have implemented these programs, funding has come from two major sources: TANF funds and state general funds. ${ }^{26}$ Other areas for housing policy development include credit counseling and homeowner education programs. 


\section{Family Income Support}

Analyses presented in this issue brief underscore the importance of full-time work for families' well-being. One challenge of full-time work for adults in low-income families is their level of workforce preparation. Another challenge is the nature of employment available to adults with less education and few skills. For many of these adults, the only option offered by employers is part-time work. When full-time work is available to these adults, there is often less flexibility in scheduling, fewer benefits (e.g., employee health insurance and paid leave), and less opportunity for promotion. These challenges highlight the necessity of work preparation policies, considered above, and family income support policies.

Low-income families' ability to achieve economic stability and meet basic needs requires attention to policies that provide income support for families in the state. For example, the federal Earned Income Tax Credit (EITC) is a federal tax credit available to low-income, working families. The most recent estimates indicate that 92 percent of individuals eligible for the federal EITC filed for the credit in 1996, one of the highest rates in the country. ${ }^{27}$ Studies show that earnings supplements, including the EITC and others, can help low-income families stay intact and can improve children's behavior and achievement in school. ${ }^{28}$

Over half of the state's low-income children live in a family headed by a young adult. Young adults' economic security is therefore an important policy consideration. Education and training, as discussed above, are important areas of policy consideration. Housing policy, also discussed above, are particularly relevant to young families trying to enter the housing market.

The state minimum wage also applies broadly to low-income families with working adults. At its current level of $\$ 5.15$ per hour, the state minimum wage means some adult workers cannot earn a livable wage that can support a family. Analyses in this brief indicate that a large percentage of fulltime workers in New Hampshire's low-income families earn at or below the minimum wage. Although many assume that minimum wage is an entry-level wage that increases with time spent in the labor force, other analyses indicate that the wage may not be temporary for a considerable portion of adult minimum wage workers. ${ }^{29}$ Proposed increases in the minimum wage could bolster workers' earnings and promote economic self-sufficiency for 28 percent of New Hampshire's low-income families.

Over half of the state's low-income children live in a single mother family. Child support policy is therefore critical to addressing single mothers' economic instability. The New Hampshire Division of Child Support Services enforces financial and child support orders, but there is little coordination of child support policy and other social support policy in the state. In particular, all child support income is presently considered in determining single mothers' TANF eligibility, which may decrease the financial resources available to custodial parents. To coordinate resources available to custodial parents, some states allow a portion of the child support payment amount to "pass through" when establishing TANF eligibility and benefits. ${ }^{30}$

The adults and children that comprise New Hampshire's low-income families live in a precarious position. For the one in seven families that live at or near the poverty level in the state, even small fluctuations in their family, employment, or the economy can spur economic instability. Because these families comprise a considerable portion of the state's families, state policy that targets increasing income and resources for low-income families is an investment in New Hampshire's future.

\section{Data Used in this Report}

Figures cited in this report are based on the author's analysis of data from the 2000 Public Use Microdata Sample (PUMS) and the 2005 American Community Survey (ACS). Both surveys are conducted by the U.S. Bureau of the Census. PUMS data is comprised of information collected from the "long form" during the decennial census. The long form was administered to a nationally representative 5 percent sample of households and individuals living in those households. The ACS is replacing the long form in future censuses by collecting the same detailed data on an annual basis from a smaller, nationally representative sample. Both datasets contain the demographic information normally gathered from all households during the decennial census, but also include detailed information on family composition, place of residency, family income and expenses, and personal income and employment. Respondents are asked to provide this information for the previous year (i.e., 2005 ACS data refers to respondents' circumstances in 2004). When applicable, dollar amounts in the PUMS data were adjusted for inflation to 2004 dollars. 


\section{Endnotes}

${ }^{1}$ DeNavas-Walt, Carmen, Bernadette D. Proctor, and Cheryl Hill Lee. 2005. "Income, Poverty, and Health Insurance Coverage in the United States: 2004." Current Population Reports P60-229. Washington, DC: United States Bureau of the Census.

${ }^{2}$ National Center for Children in Poverty. 2006. "Who Are America's Poor Children?" New York: National Center for Children in Poverty. Retrieved December 7, 2006 (http:// www.nccp.org/pub_cpt05b.html).

${ }^{3}$ New Hampshire Economic and Labor Market Information Bureau. 2006. Vital Signs 2006: Economic and Social Indicators for New Hampshire, 2001-2004. Concord, NH: Economic and Labor Market Information Bureau of the New Hampshire Employment Security.

${ }^{4}$ Churilla, Allison. 2006. The State of Working New Hampshire 2006. Durham, NH: Carsey Institute.

${ }^{5}$ In this report, "low-income" is used to refer to families whose total family income in 2004 fell below 200 percent of the federal poverty threshold. In 2004, the federal poverty threshold for a family of four was $\$ 18,850$; a family of four earning less than $\$ 37,700$ would therefore be considered low-income in this analysis. For more information on the 2004 federal poverty threshold, see http://aspe.hhs.gov/ poverty/04poverty.shtml.

${ }^{6}$ Kenyon, Daphne. 2006. "New Hampshire's Basic Needs and Livable Wage 2006." Concord, NH: UNH Office of Economic Initiatives and North Country Council, Inc.

${ }^{7}$ For married couple families, both married partners are included in demographic tabulations presented in Table 2. As a result, the number of family heads in Table 2 exceeds the number of families presented in Table 1 . Also note that the number of family heads in Table 2 is less than the total number of adults in Table 1 because other related adults may be present in some families (e.g., adult children).

${ }^{8}$ An "employment disability" is defined as a mental, physical, or emotional condition lasting 6 months or more that makes it difficult to work at a job or business.

${ }^{9}$ For this report, two other family income categories were constructed for purposes of comparison: middle-income families (200-399 percent of the poverty threshold) and high-income families ( 400 percent of the poverty threshold and above).

${ }^{10}$ This figure controls for family size by using a per capita measure of median family income in 1999 and 2004.

${ }^{11}$ Families in poverty are those whose total family income fell below the federal poverty threshold in 2004, while those in severe poverty fell below half of the poverty line.
${ }^{12}$ Lipman, Barbara J. 2006. "Locked Out: Keys to Homeownership Elude Many Working Families with Children." Washington, DC: Center for Housing Policy.

${ }^{13}$ In this report, a family experiences "crowding" if there are more family members than bedrooms in a residence. For married couple families, the married couple is assumed to share a bedroom.

${ }^{14}$ United States Bureau of Labor Statistics. 2006. Occupational Outlook Handbook, 2006-2007 Edition. Washington, DC: United States Department of Labor. Retrieved November 3, 2006 (http://www.bls.gov/oco/home.htm).

${ }^{15}$ Federal minimum wage in 2004 was $\$ 5.15 /$ hour. Hourly wages were computed by dividing workers' annual earnings from wages, salary, and self-employment income by the product of their typically weekly hours and weeks worked in 2004. This computation of an hourly wage is an approximation and does not account for other forms of worker compensation (e.g., benefits).

${ }^{16}$ In this publication, the term "young children" refers to children under 6 years of age and "school-aged children" are children between 6 and 17 years of age. The term "young adults" is used to refer to adults in their twenties and thirties.

${ }^{17}$ An unmarried partner is distinguished from a roommate by the type of relationship maintained with the head of household. Unmarried partners have a "close personal relationship" with the householder, whereas roommates share living quarters with the householder primarily to share living expenses. Unmarried partners' income is not included in family income calculations.

18 "Cash public assistance" refers to Temporary Assistance for Needy Families and other forms of general cash assistance. It does not include reimbursement for medical expenses or noncash benefits.

${ }^{19}$ Percentages were obtained by dividing annual cost of rent/mortgage by annual family income. Average percentage reported is median value for all families in that category.

${ }^{20}$ A ratio of the number of family members in a household to the number of bedrooms gives a rough measure of "crowding." A number greater than one indicates that there are more family members than bedrooms, suggesting the household faces crowding issues.

${ }^{21}$ Allegretto, Sylvia. 2005. "Basic Family Budgets: Working Families' Incomes Often Fail to Meet Living Expenses Around the U.S." EPI Briefing Paper No. 165. Washington, DC: Economic Policy Institute. Retrieved November 29, 2006 (http://www.epinet.org/briefingpapers/165/bp165.pdf). 
22 Bravo, Noel and Minh Ta. 2006. "Policy Matters State Policy Brief - January 2006: New Hampshire.” Washington, DC: Center for the Study of Social Policy.

${ }^{23}$ Commonly understood as welfare, TANF is a federally-funded program administered at the state level that provides cash assistance to working families. Eligibility for participation in TANF is based on income and family size. States differ in their requirements to maintain eligibility, but enrollment in the program generally requires adult family members to engage in work and related activities for a specified number of hours each week. The lifetime limit on participation in the program is five years.

${ }^{24}$ Administration for Children and Families. 2006. "Child Care and Development Fund: Average Monthly Adjusted Number of Families and Children Served (FY 2004)." Department of Health and Human Services, Washington, DC. Retrieved November 9, 2006 (http://www.acf.hhs.gov/ programs/ccb/research/04acf800/table1.htm).

${ }^{25}$ United States Bureau of the Census. 2006. "American Community Survey 2005 Housing - Financial Characteristics." Washington, DC: United States Bureau of the Census. Retrieved November 29, 2006 (http://factfinder.census.gov/ servlet/ACSSAFFHousing?_sse=on\&_submenuId=housing 2).

${ }^{26}$ McNichol, Liz and John Springer. 2004. "State Policies to Assist Working-Poor Families.” Washington, DC: Center on Budget and Policy Priorities.

${ }^{27}$ Internal Revenue Service. 2002. "Participation in the Earned Income Tax Credit Program for Tax Year 1996." Internal Revenue Service Fiscal Year Research Project \#12.26. Lanham, MD: Internal Revenue Service - Small Business Self Employed. Retrieved December 11, 2006 (http://taxpolicycenter.org/TaxFacts/papers/irs_eitc.pdf).

${ }^{28}$ Duncan, Greg J., Aletha C. Huston, and Thomas S. Weisner. 2005. New Hope: A Policy Success for Working Poor Families and Their Children.

${ }^{29}$ Boushey, Heather. 2005. "No Way Out: How Prime-Age Workers Get Trapped in Minimum Wage Jobs." Working USA: The Journal of Labor and Society 8: 659-670.

${ }^{30}$ Bravo and Ta. 2006. "Policy Matters State Policy Brief."

\section{A U T H O R}

Allison Churilla is a Policy Fellow at the Carsey Institute and a PhD Candidate in the Department of Sociology at the University of New Hampshire (allison.churilla@unh.edu).

\section{A C K N O W L E D G E M E N T S}

The author would like to thank Ellen Shemitz, President of the New Hampshire Children's Alliance, and Deborah Schachter, Senior Program Officer at the New Hampshire Charitable Foundation, for their helpful insights on state policy. The author would also like to acknowledge the thoughtful comments provided by Cynthia Duncan, Kristin Smith, and Sally Ward on earlier versions of this brief. Financial support was provided by the Pilot Fund and the Durum Fund of the New Hampshire Charitable Foundation. Responsibility for the analysis lies with the Carsey Institute.

\section{A UNIVERSITY Ail of NEW HAMPSHIRE}

\section{CARSEY \\ I N S T I T U T E}

Building knowledge for families and communities in the 21st Century.

The Carsey Institute at the University of New Hampshire conducts independent, interdisciplinary research and communicates its findings to policymakers, practitioners and the general public.

Huddleston Hall

73 Main Street

Durham, NH 03824

(603) $862-2821$

www.carseyinstitute.unh.edu

This brief is part of a series of Carsey Institute Reports on Changes in New England. 